\title{
A ruthenium-oligonucleotide bioconjugated photosensitizing aptamer for cancer cell specific photodynamic therapy
}

Luke K. McKenzie ${ }^{\mathrm{a}, \mathrm{b}} \uparrow$, Marie Flamme ${ }^{\mathrm{a}, \mathrm{b}, \mathrm{c}} \uparrow$, Patrick S. Felder ${ }^{\mathrm{b}}$, Johannes Karges ${ }^{\mathrm{b}}$, Frederic Bonhomme $^{\mathrm{d}}$, Albert Gandioso $^{\mathrm{b}}$, Christian Malosse $^{\mathrm{e}}$, Gilles Gasser $^{\mathrm{b} *}$, Marcel Hollenstein ${ }^{\mathrm{a} *}$

a Institut Pasteur, Department of Structural Biology and Chemistry, Laboratory for Bioorganic Chemistry of Nucleic Acids, CNRS UMR3523, 28 rue du Docteur Roux, 75724 Paris Cedex 15, France.

${ }^{\mathrm{b}}$ Chimie ParisTech, PSL University, CNRS, Institute of Chemistry for Life and Health Sciences, Laboratory for Inorganic Chemical Biology, 75005 Paris, France.

${ }^{c}$ Université de Paris, 12 rue de l'École de Médecine, 75006 Paris, France.

${ }^{\mathrm{d}}$ Institut Pasteur, Department of Structural Biology and Chemistry, Unité de Chimie

Biologique Epigénétique, UMR CNRS 3523, 28 rue du Docteur Roux, 75724 Paris Cedex 15, France

e Institut Pasteur, Mass Spectrometry for Biology Unit, 28 rue du Docteur Roux, 75724 Paris Cedex 15, France.

$\dagger$ authors contributed equally

*Email: gilles.gasser@chimieparistech.psl.eu; Tel. $\quad+33 \quad 1 \quad 85 \quad 78 \quad 41$ 51; Website: www.gassergroup.com; marcel.hollenstein@pasteur.fr; Tel. +33 1443894 66; Website: https://research.pasteur.fr/en/team/bioorganic-chemistry-of-nucleic-acids/

ORCID-ID:

Luke McKenzie: 0000-0002-0955-9447

Marie Flamme: 0000-0003-1904-5017

Patrick Felder: 0000-0003-2325-9026

Johannes Karges: 0000-0001-5258-0260

Frederic Bonhomme: 0000-0001-6797-289X 
Albert Gandioso: 0000-0002-5114-8502

Gilles Gasser: 0000-0002-4244-5097

Marcel Hollenstein: 0000-0003-0263-9206

Keywords: Anticancer, Aptamer, Medicinal Inorganic Chemistry, Metals in Medicine, Photosensitiser; Photodynamic Therapy. 


\begin{abstract}
Ruthenium complexes have emerged as a promising class of compounds for use as photosensitizers (PSs) in photodynamic therapy (PDT) due to their attractive photophysical properties and relative ease of chemical alteration. While promising, they generally are not inherently targeting to disease sites and may therefore be prone to side effects and require higher doses. Aptamers are short oligonucleotides that bind specific targets with high affinity. One such aptamer is AS1411, a nucleolin targeting, G-quadruplex forming, DNA aptamer. Here we present the first example of direct conjugation of a $\mathrm{Ru}(\mathrm{II})$ polypyridyl complex-based PS to an aptamer and an assessment of its in vitro cancer cell specific photosensitization including discussion of the challenges faced.
\end{abstract}




\section{Introduction}

The exploration of ruthenium $(\mathrm{Ru})$ complexes for use as photosensitizers (PSs) for photodynamic therapy (PDT) has exploded in recent years ${ }^{1-13}$ and, with the recent entrance into clinical trials of the Ru(II)-based PS TLD-1433, this looks only likely to intensify. ${ }^{7}$ PDT combines a PS, activating light and cellular oxygen to produce ${ }^{1} \mathrm{O}_{2} /$ reactive oxygen species (ROS) resulting in localised cell death. ${ }^{3}$ While PDT of cancer promises tumour specificity through localised irradiation at the tumour site, the PS has generally only a low cancer cell specificity. A number of strategies have been investigated to enhance the cancer specificity and/or organelle specific targeting of Ru-based PDT PSs such as bioconjugation to proteins ${ }^{11}$, 14-16 and nanobodies ${ }^{17}$ as well as through nanoparticle incorporation. ${ }^{18-22}$ This would allow for the use of lower doses of PS and the reduction of side effects.

One targeting modality, little explored in combination with ruthenium complexes, is the use of aptamers. ${ }^{23}$ Aptamers are short oligonucleotides with high binding affinity to a specific target, such as proteins or entire cells, and are usually selected through the Systematic Evolution of Ligands by Exponential enrichment (SELEX) process. ${ }^{24-26}$ Aptamers are considered to be nucleic acid analogues of antibodies but offer a number of advantages such as synthetic reproducibility and comparatively low-cost, high scale, synthesis. One such aptamer is AS1411, unusually discovered accidentally rather than through the traditional SELEX process. ${ }^{27} \mathbf{A S 1 4 1 1}$ is an aptamer for nucleolin, a protein generally expressed in the nucleoli of cells, though overexpressed in a wide number of cancer cell lines with atypical cell surface expression. ${ }^{28} \mathbf{A S 1 4 1 1}$ has been shown to be internalised in many cancer cells lines such as breast (MCF7) and prostate (DU145), among many others, while normal cell lines typically do not incorporate the aptamer. ${ }^{29}$ The G-rich oligonucleotide forms a G-quadruplex in the presence of certain metal ions such as $\mathrm{K}^{+}$and this formation is believed to be required for uptake. AS1411 has been explored as a potential cancer specific drug delivery system with 
drug loading via intercalation ${ }^{30}$ as well as through covalent linking. ${ }^{31,32}$ Kim et al. recently conjugated the known PS Ce6 to the 3'-end of AS1411 via a PEG chain. Photosensitization in the nanomolar range was observed for the resulting aptamer in three cancer cell lines (MCF-7, HCT 116, and SKOV-3) while no photosensitization was observed in a normal cell line (L929) ${ }^{33}$. A number of papers have been released exploring the use of AS1411 for targeted PDT including both direct conjugation ${ }^{33,34}$ and intercalation ${ }^{30}$. Previously, the ruthenium complex $\left[\mathrm{Ru}(\mathrm{bpy})_{2}(\mathrm{tip})\right]^{2+}$ was loaded into nanoparticles adorned with AS1411 for cell specific release with the system improving survival in a murine glioma model. ${ }^{35}$ The direct use of Ruthenium complexes with AS1411 in this context poses some previously unexplored questions. Certain ruthenium complexes are known to interact with G-quadruplexes, for example a series of dinuclear Ruthenium complexes were shown to bind to and stabilise telomeric Gquadruplexes. ${ }^{36}$ While many Ruthenium complexes have been demonstrated to specifically target, and usually stabilize, G-quadruplex DNA over standard DNA duplexes. ${ }^{36-44}$ As such we faced the question of whether to approach the system via intercalation, as demonstrated previously with the non-ruthenium PS $\mathbf{T M P y P} \mathbf{P}^{30}$ or by conjugation, eventually settling with the latter due to questions of complete intercalation would be achieved and whether intercalation may result in quenching and reduction of ${ }^{1} \mathrm{O}_{2}$ yields.

We recently published our findings of a series of rationally designed $\mathrm{Ru}(\mathrm{II})$ polypyridine complexes based on the $\left[\mathrm{Ru}(\mathrm{phen})_{2}(\mathrm{bpy})\right]^{2+}$ scaffold of which one complex (Ru) was demonstrated to be capable of remarkable photosensitization in the nanomolar range at $595 \mathrm{~nm}$ (Figure 1a). ${ }^{1}$ Capitalizing on the excellent results obtained by Kim et al., we decided to investigate whether the coupling of $\mathbf{R u}$ to this aptamer would indeed allow for selective targeting of cancer cells. In this article, we describe the design, synthesis, biophysical characterization, and in vitro evaluation of a series of ruthenium-AS1411 conjugates (RuAS1411) utilizing Ru in combination with the cancer-targeting aptamer AS1411. ${ }^{1}$ 
a)

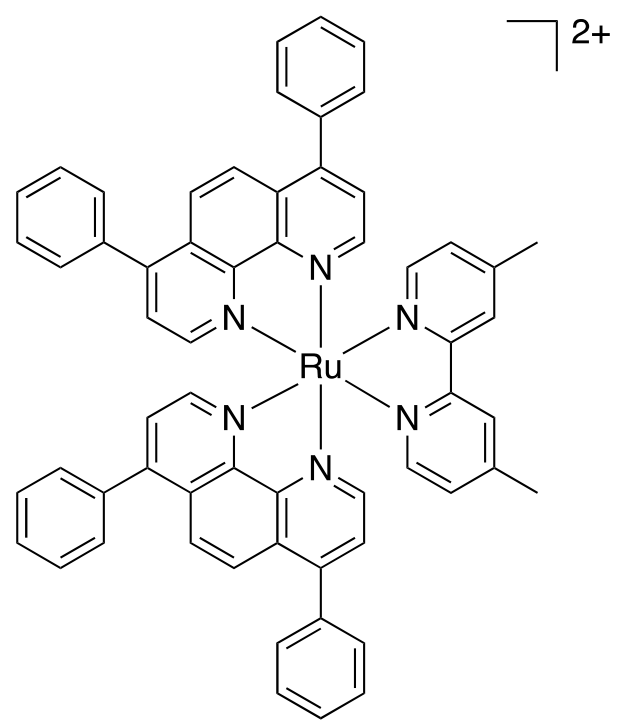

b)

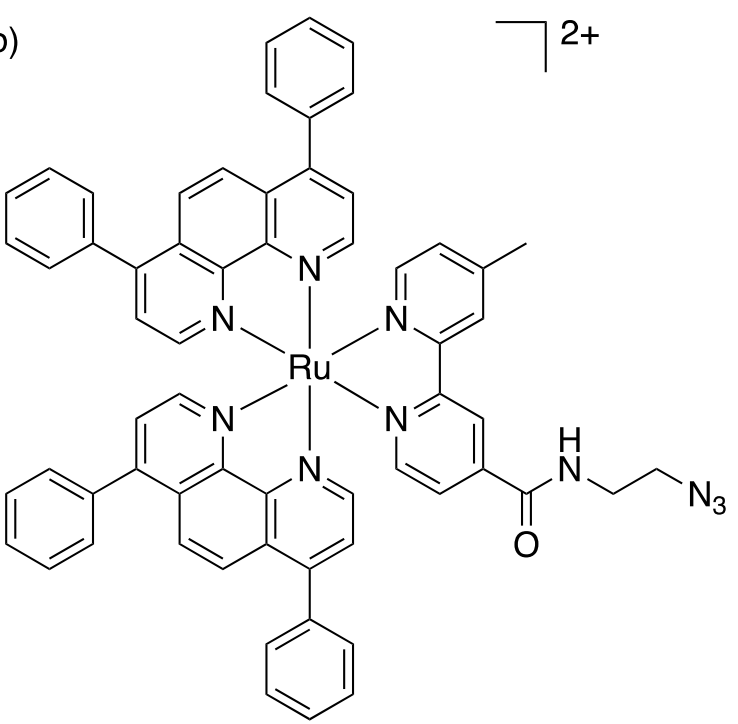

Figure 1. Chemical structures of a) $\mathbf{R u}^{1}$; b) $\mathbf{R u N}_{\mathbf{3}}$.

6 


\section{Results and discussion}

\section{Synthesis and characterisation}

The previously reported Ru (Figure 1a) was chosen for conjugation to AS1411 due to its remarkable photophysical and photosensitizing properties at wavelengths up to $595 \mathrm{~nm} .^{1}$ Through the addition of an azide functionality on the bipyridine ligand, the resulting $\mathrm{Ru}(\mathrm{II})$ complex $\left(\mathbf{R u N}_{3}\right)$ (Figure 1b) is primed to form the ruthenium-containing aptamer conjugates (Ru-AS1411s, Figure S1) through the standard $\mathrm{Cu}(\mathrm{I})$-catalyzed azide-alkyne cycloaddition (click) reaction. The AS1411 aptamer consists of a 26 mer sequence (template T1, Table 1). With the rationale of reduced G-quadruplex disruption, three spacer Ts were appended at the 3'- end followed by 3' alkyne modification resulting in the 29 mer sequence T2 (Table 1). We also designed sequences $\mathbf{T 3}$ and $\mathbf{T 4}$ where the alkyne moiety is placed at the 5 ' rather than at the 3' position of AS1411 aptamer to probe the effect on PDT efficiency and G-quadruplex formation capacity and with shorter (T3) and longer (T4) connecting linker moieties.

\begin{tabular}{|l|l|}
\hline Oligonucleotide & Sequence \\
\hline T1 & 5'-GGT GGT GGT GGT TGT GGT GGT GGT GG-3' \\
\hline T2 & 5'- GGT GGT GGT GGT TGT GGT GGT GGT GGT TT-alkyne' ${ }^{\prime}$ ' ' \\
\hline T3 & 5'-alkyne ${ }^{2}$ - TTG GTG GTG GTG GTT GTG GTG GTG GTG G-3' \\
\hline T4 & 5'-alkyne ${ }^{2}$ - TTT TTG GTG GTG GTG GTT GTG GTG GTG GTG G-3' \\
\hline T5 & 5'-FAM-GGT GGT GGT GGT TGT GGT GGT GGT GG-3' \\
\hline
\end{tabular}

Table 1. Sequences of the oligonucleotides used. Structure of alkyne ${ }^{1}$ and alkyne ${ }^{2}$ can be found in Figure S2.

\section{RuN3 synthesis}

The synthesis of $\mathbf{R u N}_{3}$ was achieved by adapting previously published procedures. ${ }^{45-50}$ The synthesis of [RuBphen $\mathbf{C l}_{2}$ ] was found to be more efficient via the intermediate $\left[\mathbf{R u}(\mathbf{d m s o})_{4} \mathrm{Cl}_{2}\right]$ (Erreur ! Source du renvoi introuvable.) than by direct synthesis from 
commercially available $\mathrm{RuCl}_{3}$, a finding that has been hinted at in the literature. ${ }^{45} \mathrm{LiCl}$ is used as an additive during the synthesis of $\left[\mathbf{R u B p h e n} \mathbf{C}_{2} \mathbf{C l}_{\mathbf{2}}\right]$ to prevent the formation of the trisubstituted $\left[\mathbf{R u}(\mathbf{B p h e n})_{3}\right] \mathbf{C l}_{2}$ as an undesired side product $(\mathbf{B p h e n}=4,7$-diphenyl-1,10phenanthroline, also known as bathophenanthroline). The synthesis of bpyNa was performed via EDCI-based amide coupling. 4'-methyl-[2,2'-bipyridine]-4-carboxylic acid is commercially available while 2-azidoethan-1-amine $\left(\mathbf{N}_{3} \mathbf{E t} \mathbf{N H}_{2}\right)$ was produced by nucleophilic substitution of 2-chloroethylamine with sodium azide. ${ }^{51}$ The ligand $\mathbf{b p y N} \mathbf{3}$ was directly coordinated to the $\mathrm{Ru}(\mathrm{II})$ precursor $\left[\mathbf{R u B p h e n} \mathbf{C l}_{\mathbf{2}}\right]$ to obtain $\mathbf{R u N}_{\mathbf{3}}$.

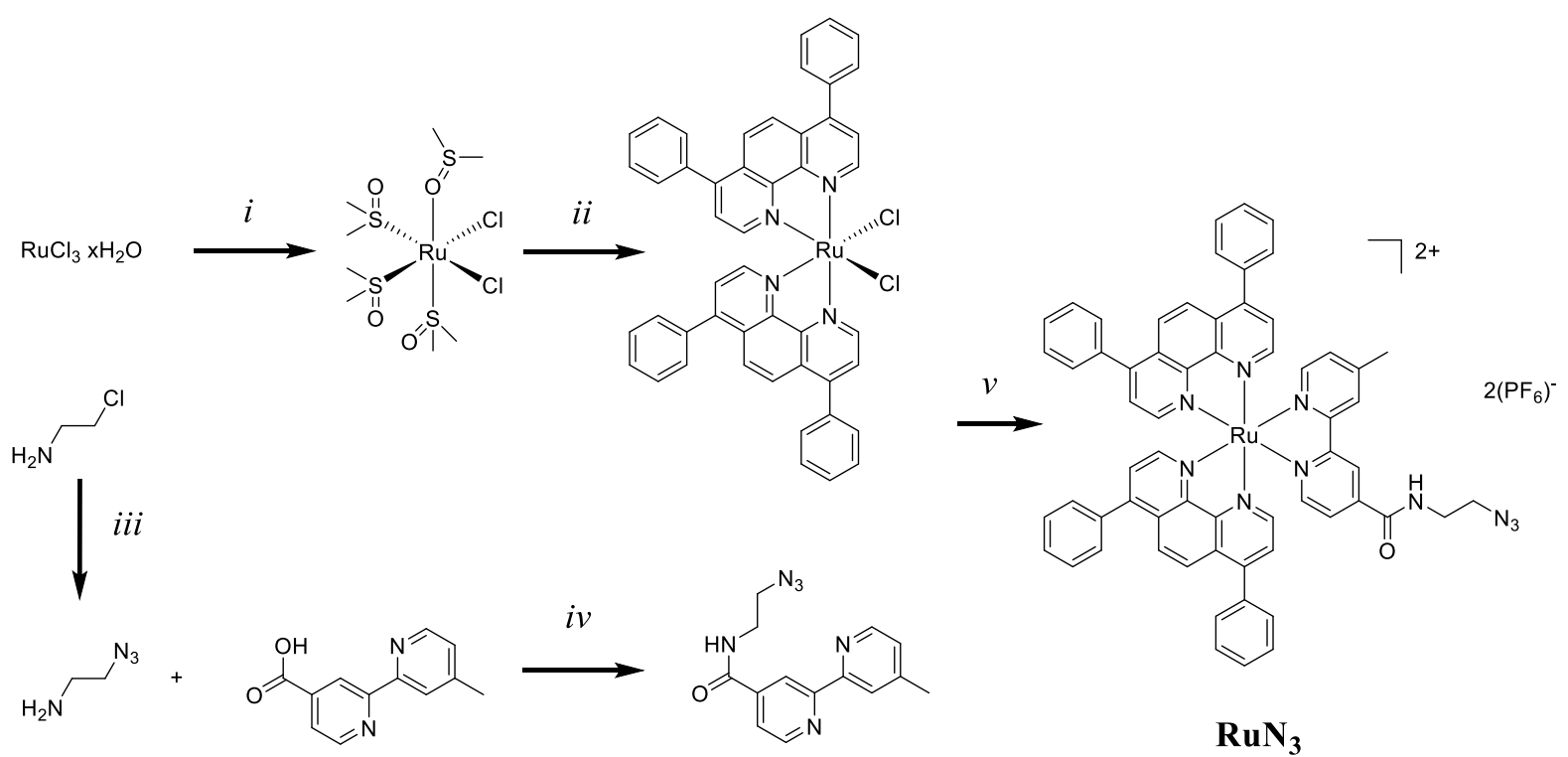

Figure 2. Synthetic procedure for $\mathbf{R u N}_{3}$; i) EtOH DMSO, reflux, $4 \mathrm{~h}$; DMSO, $125^{\circ} \mathrm{C}, 1 \mathrm{~h}, 85 \%$; ii) Bphen, $\mathrm{LiCl}$, DMF, reflux, $5 \mathrm{~h}, 72 \%$; iii) $\mathrm{NaN}_{3}, \mathrm{H}_{2} \mathrm{O}, 80^{\circ} \mathrm{C}, 12 \mathrm{~h}, 82 \%$; iv) EDCI, NHS, DIPEA, $\mathrm{CH}_{2} \mathrm{Cl}_{2}$, r.t., $12 \mathrm{~h}, 56 \%$; v) $\mathrm{MeOH}, \mathrm{H}_{2} \mathrm{O}$, reflux, 15 h, $64 \%$.

RuN3 was fully characterized by NMR (Figures S3-S8), HR-MS ESI (Figure S9) and IR spectroscopy (Figure S10). Present are the characteristic patterns of the disubstituted phen and bpy ligands $(8.0-9.0 \mathrm{ppm})$, as well as the rotating phen groups $(7.5 \mathrm{ppm}$, broad $)$, the four protons of the aliphatic $\mathrm{EtN}_{3}$ end $(3.5-3.6 \mathrm{ppm})$ and the three methyl protons $(2.6 \mathrm{ppm})$, the structure was successfully identified by ${ }^{1} \mathrm{H}$ NMR (Figure S3). The molecular formula of RuN3 was confirmed by (ESI) HR-MS $\left(\mathrm{C}_{62} \mathrm{H}_{46} \mathrm{~N}_{10} \mathrm{ORu}\right.$, expected: 524.1453, found: 524.1447) in 
positive mode as the $[\mathrm{M}]^{2+}$ ion (Figure S9). The characteristic azide peak in the IR spectra was identified at $2100 \mathrm{~cm}^{-1}$ (Figure S10).

\section{$\mathrm{RuN}_{3}$ Photophysical and biological analyses}

The absorption spectrum of RuN3 (Figure S11a) exhibits the two Soret bands typical for this type of Bphen-containing $\mathrm{Ru}(\mathrm{II})$ complex. ${ }^{4}, 48,52-54$ The local maximum at $470 \mathrm{~nm}$, with bathochromic off-tailing up to $600 \mathrm{~nm},{ }^{48,53}$ is associated with the PDT-active metal-to-ligand charge transfer (MLCT) band. $\mathbf{R u N}_{\mathbf{3}}$ has a large Stokes shift $(0.74 \mathrm{eV})$ with an emission maximum at $640 \mathrm{~nm}$ (in acetonitrile, Figure S11b) and a luminescence quantum yield of $\Phi=$ $2.6 \%$ in comparison to $\left[\mathrm{Ru}(\mathrm{bpy})_{3}\right] \mathrm{Cl}_{2}(\Phi=5.9 \%)^{55}$. The excited state lifetime was determined to be $220 \mathrm{~ns}$ in an air-saturated and $1076 \mathrm{~ns}$ in a degassed environment, which is comparable with $\left[\mathrm{Ru}(\mathrm{bpy})_{3}\right] \mathrm{Cl}_{2 .}{ }^{2,48,53}$ The change of the excited state lifetime is indicative of an interaction of the metal complex with molecular oxygen. The singlet oxygen yield $(\Phi \Delta)$ of RuN3 was measured by both direct measurement of singlet oxygen phosphorescence and by indirect measurement using ${ }^{1} \mathrm{O}_{2}$ scavengers as previously described. ${ }^{56} \mathbf{R u N}_{\mathbf{3}}$ was found with a value of $68 \%$ using the direct method ( $\lambda_{\text {exc }}=450 \mathrm{~nm}$, acetonitrile), similarly to $\mathbf{R u}$ under the same conditions $\left(61 \%^{1}\right)$. The $\Phi \Delta$ upon excitation at $595 \mathrm{~nm}$ was still impressive (51\% in acetonitrile,

Table 2) indicating suitability for use as a PS over a range of activation wavelengths.

\begin{tabular}{|l|l|l|l|ll|l|l|l|l|l|}
\hline & \multicolumn{4}{l|}{ Spectroscopic properties } & \multicolumn{3}{l|}{ Singlet oxygen yield (\%) } \\
\hline & UV/Vis & $\lambda_{\mathrm{em}}$ & $\Phi_{\mathrm{em}}$ & $\tau$ & air & $\tau$ & 450 & $450 \mathrm{~nm}$ & $540 \mathrm{~nm}$ & $595 \mathrm{~nm}$ \\
& & $(\mathrm{~nm})$ & $(\%)$ & saturated & degassed & $\mathrm{nm}$ & indirect & indirect & indirect \\
& & & & $(\mu \mathrm{s})$ & $(\mu \mathrm{s})$ & direct & & & \\
\hline RuN3 & & $640^{\mathrm{a}}$ & $2.6^{\mathrm{a}}$ & $0.220^{\mathrm{a}}$ & $1.076^{\mathrm{a}}$ & $68^{\mathrm{a}}$ & $71^{\mathrm{a}}, 7^{\mathrm{b}}$ & $64^{\mathrm{a}}, 5^{\mathrm{b}}$ & $51^{\mathrm{a}}, 3^{\mathrm{b}}$ \\
\hline
\end{tabular}

Table 2. Spectroscopic properties and singlet oxygen yield measurements for $\mathbf{R u N}_{\mathbf{3}}$; a) acetonitrile; b) PBS. 
Next, RuN3 was tested in MCF-7 (breast cancer) and RPE-1 (normal retina) cell lines to determine its light and dark toxicities with irradiation at $480 \mathrm{~nm}\left(10 \mathrm{~min}, 3.21 \mathrm{~J} \mathrm{~cm}^{-2}\right)$ and 595 $\mathrm{nm}\left(2 \mathrm{~h}, 22.47 \mathrm{~J} \mathrm{~cm}^{-2}\right)$ (Table 3). The results indicate that addition of the linker does not hinder the photosensitizing action of $\mathbf{R u N}_{\mathbf{3}}$ while addition of the azide linker appears to generally reduce the dark toxicity of the molecule compared to $\mathbf{R u}{ }^{1}$

\begin{tabular}{|c|c|c|c|c|c|c|}
\hline & \multicolumn{6}{|c|}{$\mathrm{RuN}_{3}$} \\
\hline & \multicolumn{3}{|c|}{$480 \mathrm{~nm}$} & \multicolumn{3}{|c|}{$595 \mathrm{~nm}$} \\
\hline & light & dark & PI & light & dark & PI \\
\hline MCF-7 & $\begin{array}{c}0.574 \\
( \pm 0.060)\end{array}$ & $>100$ & $>174$ & $\begin{array}{c}2.081 \\
( \pm 0.050)\end{array}$ & $>100$ & $>48.05$ \\
\hline RPE-1 & $\begin{array}{c}0.015 \\
( \pm 0.069)\end{array}$ & $\begin{array}{c}58.58 \\
( \pm 0.086)\end{array}$ & 3905 & $\begin{array}{c}0.946( \pm \\
0.150)\end{array}$ & $\begin{array}{c}69.31 \\
( \pm 0.166)\end{array}$ & 73.3 \\
\hline
\end{tabular}

Table 3. $\mathrm{LD}_{50}$ Values $(\mu \mathrm{M})$ for $\mathbf{R u N}_{3}$ in the light $480 \mathrm{~nm}\left(10 \mathrm{~min}, 3.21 \mathrm{~J} \mathrm{~cm}^{-2}\right)$ or $595 \mathrm{~nm}(2 \mathrm{~h}$, $22.47 \mathrm{~J} \mathrm{~cm}^{-2}$ ) and dark in MCF-7 and RPE-1 cell lines.

\section{Ru-AS1411 conjugates}

Click reactions were chosen for conjugation due to perceived ease and accessibility. ${ }^{57-59} \mathrm{We}$ initially followed the reaction conditions set out in a paper describing the ideal click conditions for use with oligonucleotides. ${ }^{60}$ The initial click reactions were between $\mathbf{R u N}_{3}$ and $\mathbf{T} 2$ aiming to yield the system AS1411-3'-TTT-Ru. To avoid intercalation of RuN3 during the reaction the phosphate-buffered saline (PBS) in the published protocol was replaced with tris-buffered saline to avoid $\mathrm{K}^{+}$and hence G-quadruplex formation. Similarly, the 'Monarch ${ }^{\circledR}$ PCR \& DNA Cleanup Kit' was chosen for desalting the sample prior to HPLC purification as the binding buffer does not contain potassium. While PAGE of the click product confirmed conjugation (Figure S12), no G-quadruplex formation was observed by CD spectroscopy (Figure S13a). G-quadruplexes are known to produce distinctive peaks in their CD spectra when formed, as seen for AS1411 (Figure S13b), and CD spectroscopy is used as a means to validate their presence. ${ }^{61-63}$ In the case of AS1411, the distinctive CD signature includes a positive peak at around $260 \mathrm{~nm}$ and a negative peak at around $240 \mathrm{~nm}^{62,64}$ which were not observed when $\mathrm{Ru}$ was attached at the 3' end under these experimental conditions regardless on the concentration 
of $\mathrm{K}^{+}$. Nevertheless, an in vitro PDT assay was performed using MCF-7 (breast cancer), HT29 (colorectal adenocarcinoma) and RPE-1 (retinal pigment epithelial) cell lines. MCF-7 cells are cell surface nucleolin expressing cells and are widely used in in vitro tests of AS1411. An immunofluorescence assay confirmed cell surface nucleolin expression in HT-29 while no cell surface nucleolin expression was detected in RPE-1 cells (Figure S14). No PDT effect was observed following light treatment at $480 \mathrm{~nm}$ in any cell line up to $2 \mu \mathrm{M}$ (data not included). We hypothesised that this inability to form G-quadruplexes was either due to the position of the conjugated $\mathbf{R u}$ or due to guanine oxidation issues arising from the click reaction. ${ }^{65,66} \mathrm{In}$ order to investigate the $\mathbf{R u}$ hypothesis, we decided to conjugate the $\mathbf{R} \mathbf{u}$ at the 5' end with both a two $\mathrm{T}$ or five $\mathrm{T}$ spacers $\mathbf{T 3}$ and $\mathbf{T 4}$.

For the click reaction conditions in the outlined protocol, ${ }^{60} 10$ molar equivalents of $\mathrm{CuSO}_{4}$ and 50 molar equivalents of sodium ascorbate are used in thoroughly degassed solution. To investigate the effect of these click conditions on G-quadruplex formation, T2 alone (without $\mathbf{R u N}_{3}$ ) was incubated under the same conditions. Post purification no G-quadruplex melting curve was detectable, indicating potential oxidation of guanine and loss of G-quadruplex formation (Figure S15a). T2 was subsequently incubated with one molar equivalent of $\mathrm{CuSO}_{4}$ and two molar equivalents of TBTA for 1,2 and 18 hours with no loss of G-quadruplex melting curve (Figure S15a). Considering the complication encountered using click reactions in the context of conjugation of $\mathrm{Ru}(\mathrm{II})$ complexes to G-quadruplex-forming systems, we would advise the use of alternative coupling methods, or at least careful consideration of the click conditions prior to use.

The revised click conditions were used with RuN3 and T3, T4 and T2 to yield AS1411-5'-TTRu, AS1411-5'-TTTTT-Ru and AS1411-3'-TTT-Ru as monitored and purified by HPLC with confirmation of product formation by LCMS (Figure S16). G-quadruplex formation was confirmed for all three samples by CD spectroscopy (Figure S17), thermal difference spectra 
(TDS) (Figure S18) and $T_{\mathrm{m}}$-melting experiments (Figure S15b). TDS spectra can be used to analyse types of G-quadruplex formed. ${ }^{64}$ AS1411-5'-TT-Ru, AS1411-5' 'TTTTT-Ru and AS1411-3'-TTT-Ru have $T_{\mathrm{m}}$ values of $54.6,51.5$ and $61.6^{\circ} \mathrm{C}$ respectively, measured in $0.1 \mathrm{M}$ $\mathrm{KCl}$, compared to $50.0^{\circ} \mathrm{C}$ for unmodified AS1411 (T1). It is interesting to note that position of the $\mathbf{R u}$ relative to the $\mathbf{A S 1 4 1 1}$ core sequence has quite profound effects in the resulting $T_{\mathrm{m}}$ values with a very large increase of $11.6^{\circ} \mathrm{C}$ for conjugation at the 3 '-end. This perhaps indicates formation of different G-quadruplex structures or the predominance of one particular structures of the at least 8 different monomeric structures $^{62}$ known to constitute AS1411. Hence, conjugation of $\mathbf{R u}$ or possibly other substitutents might represent a means to modulate the amount and the nature of G-quadruplex structures adopted by AS1411.

All three Ru-AS1411 are prone to forming insoluble 'crystals' if dried to completion by speed vac. We hypothesise that this is due to intrastrand interactions whereby G-quadruplex formation is initiated by the conjugated ruthenium complexes. Partial solubility can be recovered by heating to $95^{\circ} \mathrm{C}$ in a $100 \mathrm{mM} \mathrm{KCl}$ solution with vigorous shaking.

\section{Biological evaluation}

All three Ru-AS1411 were tested in MCF-7 (breast cancer) and RPE-1 (normal retina) cell lines as model cell surface nucleolin positive and negative cell lines. It is clear from the CD spectrum of AS1411 that the cation concentration in the cell media used $(5 \mathrm{mM} \mathrm{KCl}, 154 \mathrm{mM}$ $\mathrm{NaCl}(\mathrm{DMEM})$ ) is insufficient for complete G-quadruplex formation (Figure S13b). As such all Ru-AS1411 were kept in stock solutions at $20 \mu \mathrm{M}$ in $50 \mathrm{mM} \mathrm{KCl}$. The additional $\mathrm{KCl}$ was kept constant across all wells including control wells. Following a 2 hour incubation and light treatment $\left(\lambda_{\mathrm{exc}}=480 \mathrm{~nm}, 3.21 \mathrm{~J} \mathrm{~cm}^{-2}, 10 \mathrm{~min}\right)$ AS1411-5'-TTTTT-Ru reduced cell viability to a greater extent in MCF7 cells compared to RPE-1 cells, demonstrating the potential for cell specific PDT (Table 4, Figure S20a). Interestingly AS1411-5'-TTTTT-Ru has a Gquadruplex $T_{\mathrm{m}}$ closest to the original sequence $\left(51.5^{\circ} \mathrm{C}\right.$ vs $\left.50.0^{\circ} \mathrm{C}\right)$ perhaps suggesting that 
AS1411-5'-TTTTT-Ru maintains the same form of G-quadruplex. Confocal microscopy confirmed an increased uptake in MCF7 cells as compared to RPE-1 cells as measured by fluorescence intensity (Figure S19). ${ }^{67}$ After a 4 hour incubation and light treatment $\left(\lambda_{\text {exc }}=480\right.$ $\mathrm{nm}, 3.21 \mathrm{~J} \mathrm{~cm}^{-2}, 10 \mathrm{~min}$ ) all three Ru-AS1411s are phototoxic and cell line specificity is lost while only a mild reduction in cell viability is seen in the dark (Table 4, Figure S20b). $\mathbf{R u N}_{3}$ alone is highly phototoxic after a 4 hour incubation in both cell lines (Table 3). Following a 2 hour incubation and light irradiation at $540 \mathrm{~nm}\left(40 \mathrm{mins}, 9.5 \mathrm{~J} \mathrm{~cm}^{-2}\right)$, AS1411-5'-TTTTT-Ru maintains phototoxicity in MCF-7 cells though at $595 \mathrm{~nm}\left(2 \mathrm{~h}, 22.47 \mathrm{~J} \mathrm{~cm}^{-2}\right)$ we were unable to detect phototoxicity within our concentration range (up to $1 \mu \mathrm{M}$ ). We believe this is due to the low range of concentrations tested coupled with the longer irradiation times.

\begin{tabular}{|c|c|c|c|c|c|c|c|c|c|c|c|c|c|}
\hline & \multicolumn{7}{|c|}{ AS1411-5'-TTTTT-Ru } & \multirow{2}{*}{\multicolumn{3}{|c|}{$\frac{\text { AS1411-5'-TT-Ru }}{480 \mathrm{~nm}}$}} & \multirow{2}{*}{\multicolumn{3}{|c|}{$\frac{\text { AS1411-3'-TTT-Ru }}{480 \mathrm{~nm}}$}} \\
\hline & \multicolumn{3}{|c|}{$480 \mathrm{~nm}$} & \multicolumn{2}{|c|}{$540 \mathrm{~nm}$} & \multicolumn{2}{|c|}{$595 \mathrm{~nm}$} & & & & & & \\
\hline & Light & dark & PI & light & dark & light & dark & light & dark & PI & light & dark & PI \\
\hline $\begin{array}{l}\text { MCF- } \\
72 \mathrm{hr}\end{array}$ & $\begin{array}{l}0.340 \\
( \pm 0.077)\end{array}$ & $>1$ & $>2.9$ & $\begin{array}{l}0.990 \\
( \pm 0.061)\end{array}$ & $>1$ & $>1$ & $>1$ & $\begin{array}{l}0.524 \\
( \pm 0.070)\end{array}$ & $>1$ & $>1.9$ & $\begin{array}{l}0.370 \\
( \pm 0.084)\end{array}$ & $>1$ & $>2.7$ \\
\hline $\begin{array}{l}\text { RPE - } \\
12 \mathrm{hr}\end{array}$ & $\begin{array}{l}0.735 \\
( \pm 0.084)\end{array}$ & $>1$ & $>1.36$ & $>1$ & $>1$ & $>1$ & $>1$ & $\begin{array}{l}0.582 \\
( \pm 0.065)\end{array}$ & $>1$ & $>1.7$ & $\begin{array}{l}0.474 \\
( \pm 0.084)\end{array}$ & $>1$ & $>2.1$ \\
\hline $\begin{array}{l}\text { MCF- } \\
74 \mathrm{hr}\end{array}$ & $\begin{array}{l}0.120 \\
( \pm 0.043)\end{array}$ & $>1$ & $>8.33$ & nd & nd & nd & nd & $\begin{array}{l}0.274 \\
( \pm 0.032)\end{array}$ & $>1$ & $>3.6$ & $\begin{array}{l}0.134 \\
( \pm 0.032)\end{array}$ & $>1$ & $>7.5$ \\
\hline $\begin{array}{l}\text { RPE - } \\
14 \mathrm{hr}\end{array}$ & $\begin{array}{l}0.082 \\
( \pm 0.058)\end{array}$ & $>1$ & $>12.19$ & nd & nd & nd & nd & $\begin{array}{l}0.231 \\
( \pm 0.047)\end{array}$ & $>1$ & $>4.3$ & $\begin{array}{l}0.181 \\
( \pm 0.059)\end{array}$ & $>1$ & $>5.5$ \\
\hline
\end{tabular}

Table 4. $\mathrm{LD}_{50}$ Values $(\mu \mathrm{M})$ for $\mathbf{R u N}_{3}$ in the light $480 \mathrm{~nm}\left(10 \mathrm{~min}, 3.21 \mathrm{~J} \mathrm{~cm}^{-2}\right), 540 \mathrm{~nm}(40$ $\left.\min , 9.5 \mathrm{~J} \mathrm{~cm}^{-2}\right), 595 \mathrm{~nm}\left(2 \mathrm{~h}, 22.47 \mathrm{~J} \mathrm{~cm}^{-2}\right)$ and dark in MCF-7 and RPE-1 cell lines.

It was hypothesized that loss of specificity at 4 hours may be due to nuclease-mediated degradation of the oligonucleotides in cell media. As such a stability test was performed in cell medium (DMEM, $10 \%$ Foetal calf serum) to investigate the degradation, if any, of the oligonucleotides (Figure S21). It is clear that AS1411 alone (with 5'-FAM, T5) is susceptible to degradation with a significant laddering in the PAGE gel from the 30-minute incubation. Where Ru conjugation is at the 3' end, in AS1411-3'-TTT-Ru, degradation appears lessen significantly, while both AS1411-5'-TT-Ru and AS1411-5'-TTTTT-Ru, where conjugation 
is at the $5^{\prime}$ end appear susceptible to degradation, though perhaps to a lesser extent when compared to AS1411.

\section{Conclusions}

In conclusion, we have successfully synthesised an azide functionalized Ruthenium complex $\mathbf{R u N}_{3}$ and obtained three Ru-AS1411 by click reaction. A thorough biophysical investigation revealed that the covalently linked $\mathrm{Ru}$ complexes did not interfere with G-quadruplex formation, especially when located at the 5'-end of AS1411. At a 2 hour incubation timepoint AS1411-5'-TTTTT-Ru was selectively photosensitizing towards a cell surface nucleolin expressing cell line (MCF-7), indicating the potential for targeting offered by this system. Overall, we demonstrate the usefulness of conjugating Ru PS to aptamers to enhance their therapeutic usefulness by conveying specificity to Ru-mediated PDT. Such an approach can readily be expanded to other aptamers by application of this straightforward method described herein and the presence of Ru PS at 5' termini is not expected to negatively impact the binding efficiency of the resulting aptamer-drug conjugates. A combination of chemically modified aptamers such as XNAs ${ }^{68-71}$ that enhance their nuclease stability with potent PS agents such as Ru complexes is expected to improve the efficiency of the PDT treatment modality in the near future.

\section{Experimental Sections}

\section{Synthesis of $\mathrm{RuN}_{3}$}

Solvents for reactions were of pro analysis (p.a.) grade or distilled prior to use. Ruthenium trichloride x-hydrate was provided by $\mathrm{I}^{2} \mathrm{CNS}$ (Zurich), 4,7-diphenyl-1,10-phenanthroline, lithium chloride (anhydrous, 99\%), and ammonium hexafluorophosphate by Alfa Aesar, sodium azide by Sigma-Aldrich. 4'-methyl-[2,2'-bipyridine]-4-carboxylic acid by FluoroChem. 
Caution! Even though no issues were encountered in this work, care should be taken during the preparation of potentially explosive azide-containing metal complexes, especially on scaled-up reactions.

\section{Instrumentation and methods}

Amber glass or clear glassware wrapped in tin foil was used when protection from light was necessary. Reactions were carried out under $\mathrm{N}_{2}$ and monitored for completion by HPLC or thinlayer chromatography. Column chromatography: Merck silica gel $60(40-63 \mu \mathrm{m})$ with the indicated solvent system. HPLC: 2x Agilent G1361 1260 Prep Pump system with Agilent G7115A 1260 DAD WR Detector equipped with an Agilent Pursuit XRs 5C18 (Analytic: $100 \AA$, C18 $5 \mu \mathrm{m} 250 \times 4.6 \mathrm{~mm}$ ) Column. The solvents (HPLC grade) were millipore water $(0.1 \%$ trifluoroacetic acid (TFA) $)$, solvent $\mathrm{A})$ and acetonitrile $(\mathrm{MeCN})(0.1 \% \mathrm{TFA}$, solvent $\mathrm{B})$. The HPLC gradients used are as follow (S1): 0-3 min: isocratic 95\% A (5\% B); 3-17 min: linear gradient from $95 \% \mathrm{~A}(5 \% \mathrm{~B})$ to $0 \% \mathrm{~A}(100 \% \mathrm{~B}) ; 17-23$ min: isocratic $0 \% \mathrm{~A}(100 \% \mathrm{~B})$, 23-25 min: linear gradient from $0 \% \mathrm{~A}(100 \% \mathrm{~B})$ to $95 \% \mathrm{~A}(5 \% \mathrm{~B})$. The flow rate was $1 \mathrm{ml} / \mathrm{min}$. Detection was performed at $215 \mathrm{~nm}, 250 \mathrm{~nm}, 350 \mathrm{~nm}, 450 \mathrm{~nm}, 550 \mathrm{~nm}$ and $650 \mathrm{~nm}$ with a slit of $4 \mathrm{~nm}$. IR spectra: SpectrumTwo FT-IR Spectrometer (Perkin-Elmer) equipped with a Specac Golden GateTM ATR (attenuated total reflection) accessory; applied as neat samples; $1 / \lambda$ in $\mathrm{cm}^{-1}$. NMR-data: Deuterated NMR solvents were obtained from Eurisotop (France). ${ }^{1} \mathrm{H}$ NMR spectra in $\mathrm{CD}_{3} \mathrm{OD}$ or $\mathrm{CD}_{3} \mathrm{CN}$; BrukerAV-400 (400 MHz); $\delta$ in ppm relative to solvent. $\left(\mathrm{CD}_{3} \mathrm{OD}\right.$ (p, $3.31 \mathrm{ppm})$ and $\mathrm{CD}_{3} \mathrm{CN}(\mathrm{p}, 1.94 \mathrm{ppm})$ ), $\mathrm{J}$ in $\mathrm{Hz} .{ }^{13} \mathrm{C}$ NMR spectra in $\mathrm{CD}_{3} \mathrm{OD}$ or $\mathrm{CD}_{3} \mathrm{CN}$; Bruker AV- 400 (100.6 MHz); $\delta$ in ppm rel. to solv. ((CD ${ }_{3} \mathrm{OD}(49.00 \mathrm{ppm})$ and $\mathrm{CD}_{3} \mathrm{CN}(118.26$ ppm)); multiplicities from DEPT-135 and DEPT-90 experiments. ${ }^{19} \mathrm{~F}$ NMR spectra in $\mathrm{CD}_{3} \mathrm{OD}$ or $\mathrm{CD}_{3} \mathrm{CN}$. electrospray ionization mass spectrometry (ESI-MS): Experiments were carried out using an LTQ-Orbitrap XL from Thermo Scientific (Thermo Fisher Scientific, Courtaboeuf, France) and operated in positive ionization mode, with a spray voltage of $3.6 \mathrm{kV}$. No sheath 
and auxiliary gay were used. Applied voltages were 40 and $100 \mathrm{~V}$ for the ion transfer capillary and the tube lens, respectively. The ion transfer capillary was held at $275^{\circ} \mathrm{C}$. Detection was achieved in the Orbitrap with a resolution set to 100.000 (at $\mathrm{m} / \mathrm{z} 400$ ) and a $\mathrm{m} / \mathrm{z}$ range between 150-2000 in profile mode. Spectrum was analyzed using the acquisition software XCalibur 2.1 (Thermo Fisher Scientific, Courtaboeuf, France). The automatic gain control (AGC) allowed the accumulation of up to $21 \times 10^{5}$ ions for FTMS scans, maximum injection time was set to $300 \mathrm{~ms}$ and $1 \mu$ scan was acquired. $10 \mu \mathrm{l}$ was injecting using a Thermo Finnigan Surveyor HPLC system (Thermo Fisher Scientific, Courtaboeuf, France) with a continuous infusion of methanol $(\mathrm{MeOH})$ at $100 \mu \mathrm{lmin}^{-1}$.

\section{$\left[\mathrm{Ru}(\mathrm{dmso}){ }_{4} \mathrm{Cl}_{2}\right]$}

$\left[\mathbf{R u}(\mathbf{d m s o})_{4} \mathbf{C l}_{2}\right]$ was synthesized by adapting a given procedure. ${ }^{45}$ Ruthenium(III)-trichloride$\mathrm{x}$-hydrate $(9.83 \mathrm{~g}, 37.6 \mathrm{mmol}$, assuming $\mathrm{x}=3)$ was suspended in EtOH (125 ml, dry) and heated to reflux for $3 \mathrm{~h}$, while a color change from dark brown to dark green was observed. The mixture was filtrated and the solv. was reduced in vacuo to afford a deep green paste. The residue was suspended in DMSO (20 ml, dry) and refluxed for $2 \mathrm{~h}$. The heating bath was turned off, and the mixture was left cooling slowly to r.t. in the oil bath while slowly stirring. Cold acetone $\left(200 \mathrm{ml}\right.$, dry) was added while stirring and the mixture was left overnight at $-25^{\circ} \mathrm{C}$ for crystallization before filtration. The solid residue was washed several times with acetone to afford $\left[\mathbf{R u}(\mathbf{d m s o})_{4} \mathbf{C l}_{2}\right]$ as yellow solid $(15.5 \mathrm{~g}, 31.9 \mathrm{mmol}, 85 \%)$. Spectroscopic data $\left({ }^{1} \mathrm{H}\right.$ NMR) were in agreement with the literature. ${ }^{45}{ }^{1} \mathrm{H}$ NMR $\left(400 \mathrm{MHz}, \mathrm{D}_{2} \mathrm{O}\right) \delta 3.58-3.31(\mathrm{~m}$, 18H), $2.71(\mathrm{~s}, 6 \mathrm{H}) .{ }^{13} \mathrm{C}$ NMR $\left(101 \mathrm{MHz}, \mathrm{D}_{2} \mathrm{O}\right) \delta$ 46.73, 46.51, 45.70, 45.11, 44.67, 44.32, 38.67.

\section{[RuBphen2 $\mathbf{C l}_{2}$ ]}

[RuBphen2 $\mathbf{C l}_{2}$ ] was synthesized by adapting a given procedure. ${ }^{72} \mathrm{~A}$ mixture of

[Ru(dmso) $\left.)_{2} \mathbf{C l}_{2}\right](3.48 \mathrm{~g}, 7.17 \mathrm{mmol})$, 4,7-diphenyl-1,10-phenanthroline (Bphen, $5.00 \mathrm{~g}$, 
$15.0 \mathrm{mmol})$ and $\mathrm{LiCl}(2.13 \mathrm{~g}, 50.3 \mathrm{mmol})$ was dissolved in DMF $(150 \mathrm{ml})$ and refluxed for $24 \mathrm{~h}$. After cooling to r.t., the solvent was reduced in vacuo and acetone $(500 \mathrm{ml})$ was slowly added while stirring. The mixture was then stored at $-25^{\circ} \mathrm{C}$ overnight for crystallization before filtration. The solid residue was washed with water, acetone and $\mathrm{Et}_{2} \mathrm{O}$ to afford [ $\mathbf{R u B p h e n} \mathbf{C l}_{2}$ ] as a black-purple solid $(3.25 \mathrm{~g}, 3.88 \mathrm{mmol}, 72 \%)$. Spectroscopic data $\left({ }^{1} \mathrm{HNMR}\right)$ were in agreement with the literature. ${ }^{72}{ }^{1} \mathrm{H}$ NMR (400 MHz, $\left.\mathrm{CD}_{2} \mathrm{Cl}_{2}\right) \delta 10.55(\mathrm{~s}, 2 \mathrm{H}), 8.50(\mathrm{~d}, J=5.5$ Hz, 1H), 8.15 (s, 1H), 8.09 (s, 1H), 8.07 (s, 1H), 7.96 (s, 2H), 7.94 (t, J = 2.8 Hz, 3H), 7.92 (s, 1H), $7.73(\mathrm{~s}, 1 \mathrm{H}), 7.69(\mathrm{~d}, J=6.9 \mathrm{~Hz}, 3 \mathrm{H}), 7.63-7.47(\mathrm{~m}, 7 \mathrm{H}), 7.46-7.34(\mathrm{~m}, 7 \mathrm{H}), 7.12(\mathrm{~d}, J=$ $5.6 \mathrm{~Hz}, 2 \mathrm{H}) .{ }^{13} \mathrm{C} \mathrm{NMR}\left(101 \mathrm{MHz}, \mathrm{CD}_{2} \mathrm{Cl}_{2}\right) \delta 154.89,153.04,152.57,151.49,150.88,149.67$, $146.37,144.96,137.08,130.63,130.18,129.52,129.40,126.10,125.85,125.63,124.90$. HPLC: $\mathrm{S} 1 \mathrm{~T}_{\mathrm{R}}=7.542 \mathrm{~min}$.

\section{$\mathrm{N}_{3} \mathrm{EtNH}_{2}$}

$\mathbf{N}_{3}$ EtNH $\mathbf{N H}_{2}$ was synthesized following a previously published method ${ }^{73} . \mathrm{NaN}_{3}(2.55 \mathrm{~g}, 39.2$ mmol) was added to a solution of 2-chloroethanamine hydrochloride (1.5g, 12.9 mmol) in $\mathrm{H}_{2} \mathrm{O}$ $(10 \mathrm{ml})$. The resulting mixture was heated with stirring at $80{ }^{\circ} \mathrm{C}$ overnight before the reaction was quenched by addition of aqueous $\mathrm{KOH}$ (dropwise until a $\mathrm{pH}$ of around 12). Following extraction by diethyl ether $(3 \times 20 \mathrm{ml})$ and washing with brine $(20 \mathrm{ml})$ the organic layers were combined and dried with anhydrous $\mathrm{MgSO}_{4}$. The solvent was removed carefully in vacuo $\left(\mathbf{N}_{3} \mathbf{E t N H}_{2}\right.$ is volatile) to give $\mathbf{N}_{3} \mathbf{E t N H}$ as a colourless oil $(1.54 \mathrm{~g}, 82 \%) .{ }^{1} \mathrm{H}$ NMR $(400 \mathrm{MHz}$, MeOD) $\delta 3.38(\mathrm{t}, 2 \mathrm{H}, \mathrm{J}=5.94 \mathrm{~Hz}), \delta 2.77(\mathrm{~m}, 2 \mathrm{H})$.

\section{bpyN3 $_{3}$}

The compound $N$-(2-azidoethyl)-4'-methyl-[2,2'-bipyridine]-4-carboxamide (bpyN3) was synthesized by suspending 4'-methyl-[2,2'-bipyridine]-4-carboxylic acid (85.70 mg, 0.40 mmol), EDCI-HCl (82.4 mg, $0.43 \mathrm{mmol})$, NHS (49.10 mg, $0.43 \mathrm{mmol})$ and in $\mathrm{CH}_{2} \mathrm{Cl}_{2}(20 \mathrm{ml})$. After addition of DIPEA $(72.0 \mu 1,0.45 \mathrm{mmol})$, the solution is getting clear while left stirring 
for $30 \mathrm{~min}$. $\mathbf{N}_{3} \mathbf{E t N H} 2(90 \mu 1,0.45 \mathrm{mmol})$ was added and the mixture was left stirring overnight. The solv. was removed in vacuo and the crude residue was purified on alumina (20:1 $\left.\mathrm{CH}_{2} \mathrm{Cl}_{2} /{ }^{i} \mathrm{PrOH}\right)$ to deliver a colourless oil. After washing with pentane, spontaneous induced crystallization delivered bpyN3 as a colorless solid (63.2 mg, 0.224 mmol, 56\%). ${ }^{1} \mathrm{H}$ NMR (400 MHz, Methanol- $\left.d_{4}\right) \delta 8.79(\mathrm{~d}, J=5.3 \mathrm{~Hz}, 1 \mathrm{H}$ arom. $), 8.68(\mathrm{~s}, 1 \mathrm{H}$ arom. $), 8.53(\mathrm{~d}, J=5.1 \mathrm{~Hz}$, 1H arom.), 8.22 (s, 1H arom.), $7.82-7.68$ (m, 1H arom.), 7.32 (d, J=5.0 Hz, 1H arom.), 3.62 $(\mathrm{t}, J=5.8 \mathrm{~Hz}, 2 \mathrm{H}), 3.55(\mathrm{~d}, J=5.8 \mathrm{~Hz}, 2 \mathrm{H}), 2.48(\mathrm{~s}, 3 \mathrm{H})$.

\section{$\mathrm{RuN}_{3}$}

The complex $\left[\mathrm{Ru}(\mathrm{Bphen})_{2}\left(\mathrm{bpyN}_{3}\right)\right]\left[\mathrm{PF}_{6}\right]_{2}\left(\mathbf{R u N}_{3}\right)$ was synthesized by adapting a given procedure. ${ }^{48}\left[\mathbf{R u}(\mathbf{B p h e n})_{2} \mathbf{C l}_{2}\right](69 \mathrm{mg}, 82 \mu \mathrm{mol})$ and bpyN3 $(31 \mathrm{mg}, 0.108 \mathrm{mmol})$ were suspended in a water/MeOH mixture $(1: 1,20 \mathrm{ml}$, degassed) and refluxed for $15 \mathrm{~h}$ resulting in a deep red solution The solution was cooled to r.t. and a few drops of saturated $\mathrm{NH}_{4} \mathrm{PF}_{6}$ solution (sat.) were added while stirring to form a red precipitate. After filtration, the crude solid was purified by column chromatography on silica 60 using a system of $\mathrm{MeCN}-\mathrm{KNO}_{3}$ aq. (20:1, $0.24 \mathrm{M})$. The product-containing phases were combined and the solv.s were removed in vacuo. The redish residue was dissolved in $\mathrm{MeOH}$ and a few drops of saturated $\mathrm{NH}_{4} \mathrm{PF}_{6}$ solution and water were added while stirring, to afford a clear solution with a red precipitate. Filtration delivered complex $\mathbf{R u N}_{3}$ as a red solid (70 mg, $\left.52 \mu \mathrm{mol}, 64 \%\right)$. IR $\left(\mathrm{cm}^{-1}\right): 2020 \mathrm{w}$, 1890s, 1620w, 1550w, 1420w, 1310w, 1220w, 1020w, 1100m, 1030w, 830s, 770s, 730m, 700m. ${ }^{1} \mathrm{H}$ NMR $\left(400 \mathrm{MHz}, \mathrm{CD}_{3} \mathrm{CN}\right) \delta 9.85(\mathrm{dd}, J=16.9,5.7 \mathrm{~Hz}, 1 \mathrm{H}), 8.89(\mathrm{~d}, J=1.4 \mathrm{~Hz}, 1 \mathrm{H}$ arom.), 8.61 (s, 1H arom.), 8.29 (dd, $J=18.9,5.5 \mathrm{~Hz}, 2 \mathrm{H}$ arom.), 8.20 (dd, $J=12.0,9.5 \mathrm{~Hz}$, $2 \mathrm{H}$ arom.), $8.19(\mathrm{~s}, 2 \mathrm{H}), 8.10(\mathrm{dd}, J=5.5,2.8 \mathrm{~Hz}, 2 \mathrm{H}$ arom.), 8.01 (dd, $J=5.9,0.6 \mathrm{~Hz}, 1 \mathrm{H}$ arom.), 7.75 (t, $J=5.5 \mathrm{~Hz}, 2 \mathrm{H}$ arom.), $7.72-7.55$ (m, 24H arom.), 7.26 (ddd, $J=5.8,1.8,0.8$ $\mathrm{Hz}, 1 \mathrm{H}$ arom. $), 3.61$ (q, $J=5.3 \mathrm{~Hz}, 2 \mathrm{H}), 3.53(\mathrm{t}, J=5.7 \mathrm{~Hz}, 2 \mathrm{H}), 2.59$ (s, 3H). ${ }^{13} \mathrm{C} \mathrm{NMR}(101$ 
$\left.\mathrm{MHz}, \mathrm{CD}_{3} \mathrm{CN}\right) \delta 153.16,153.02,152.34,150.12,143.13,136.69,136.63,130.81,130.75$, $130.69,130.65,130.15,130.11,129.99,127.05,126.49,125.13,122.55,51.03,40.30,21.28$. ${ }^{19} \mathrm{~F}$ NMR (376 MHz, $\left.\mathrm{CD}_{3} \mathrm{CN}\right) \delta-72.74\left(\mathrm{~d}, J=707.1 \mathrm{~Hz}, \mathrm{PF}_{6}\right) . \mathrm{HR}-\mathrm{MS}$ (ESI+): m/z 524.1447 $\left[\mathrm{M}-2\left(\mathrm{PF}_{6}\right)\right]^{2+}$ (calculated: 524.1453). HPLC: $\mathrm{S} 1 \mathrm{~T}_{\mathrm{R}}=16.271 \mathrm{~min}$.

\section{Click reactions}

Oligonucleotides T1, T2 and T5 were purchased from Microsynth AG, oligonucleotides T3 and T4 were ordered from Integrated DNA Technologies and were stored at $1 \mathrm{mM}$ in $\mathrm{H}_{2} \mathrm{O}$. $\mathrm{RuN}_{3}$ was stored at $5 \mathrm{mM}$ in DMF, Sodium ascorbate was made fresh at $50 \mathrm{mM}$ in $\mathrm{H}_{2} \mathrm{O}, \mathrm{CuSO}_{4}$ was stored at $5 \mathrm{mM}$ in $\mathrm{H}_{2} \mathrm{O}$, TBTA was stored at $10 \mathrm{mM}$ in DMSO. All solutions were thoroughly degassed by argon bubbling prior and post mixing of appropriate quantities of stock solutions. The reactions were performed in Eppendorf tubes at $30{ }^{\circ} \mathrm{C}$ with gentle shaking for 2 hours. The Monarch ${ }^{\circledR}$ PCR \& DNA Cleanup Kit was used to desalt the reactions before HPLC purification. The quantities of reagents used is specified in Table 5. Confirmation of product formation was obtained by LCMS (m/z found: 10082.7427, 10994.8808 and 10560.8611 for AS1411-5'-TT-Ru, AS1411-5'-TTTTT-Ru and AS1411-3'-TTT-Ru respectively)

\begin{tabular}{|l|l|l|}
\hline & Original* & Revised \\
\hline Oligonucleotide $(1 \mathrm{mM})$ & $100 \mu \mathrm{l}$ & $100 \mu \mathrm{l}$ \\
\hline $\mathbf{R u N}_{3}(5 \mathrm{mM})$ & $100 \mu \mathrm{l}$ & $100 \mu \mathrm{l}$ \\
\hline $\mathrm{CuSO}_{4}(10 \mathrm{mM})$ & $100 \mu \mathrm{l}$ & $10 \mu \mathrm{l}$ \\
\hline TBTA $(10 \mathrm{mM})$ & & $20 \mu \mathrm{l}$ \\
\hline Na ascorbate $(50 \mathrm{mM})$ & $100 \mu \mathrm{l}$ & $100 \mu \mathrm{l}$ \\
\hline Tris buffer $10 \mathrm{X}$ & $40 \mu \mathrm{l}$ & $34 \mu \mathrm{l}$ \\
\hline Acetonitrile & $10 \mu \mathrm{l}$ & $10 \mu \mathrm{l}$ \\
\hline
\end{tabular}

Table 5. Ratios of reagents used in click reactions. * not recommended 


\section{HPLC}

HPLC purification was performed using an $\ddot{A} \mathrm{kta}^{\mathrm{TM}}$ pure system (GE Healthcare) equipped with Kinetex ${ }^{\circledR}$ semi preparative Reversed Phase C18 column $(5 \mu \mathrm{m}, 250$ x $10.0 \mathrm{~mm})$. Buffer A: $20 \mathrm{mM}$ Triethylammonium acetate (TEAA) buffer; Buffer B: 30\% $20 \mathrm{mM}$ TEAA/ 70\% Acetonitrile. A flow rate of $1.5 \mathrm{ml} / \mathrm{min}$ was used with UV/Vis detection at 280 and $430 \mathrm{~nm}$.

\section{Spectroscopic measurements}

The absorption spectra of the sample was measured with a SpectraMax M2 Spectrometer (Molecular Devices). For measurement of the emission, the sample was irradiated at $450 \mathrm{~nm}$ with a NT342B Nd-YAG pumped optical parametric oscillator (Ekspla). The emission was focused at right angle to the excitation pathway and directed to a Princeton Instruments Acton SP-2300i monochromator. The signal was detected with a XPI-Max 4 CCD camera (Princeton Instruments).

\section{LC-MS}

LC-MS analyses were performed on a Q exactive mass spectrometer (Thermo Fisher Scientific) equipped with an electrospray ionisation source (H-ESI II Probe) coupled with an Ultimate 3000 RS HPLC (Thermo Fisher Scientific). Compounds were injected onto a ThermoFisher Hypersil Gold aQ chromatography column (100 mm * $2.1 \mathrm{~mm}, 1,9 \mathrm{um}$ particle size) heated at $30^{\circ} \mathrm{C}$. The flow rate was set at $0.3 \mathrm{ml} / \mathrm{min}$ and the mobile phase consisted of (A) water $+0.1 \%$ formic acid and (B) acetonitrile $+0.1 \%$ formic acid. The gradient used was : $5 \%$ B during $0-3$ minutes then $5 \%$ to $100 \%$ B linear during $3-8$ minutes. Ions were analysed in negative ion mode. MS resolution was 70,000 with an AGC target of $1^{\mathrm{e}} 6$ and a maximum injection time of $240 \mathrm{~ms}$. Multicharged ions were processed using Xtract software. A UV detector set at $270 \mathrm{~nm}$ was also used as a control.

\section{Luminescence quantum yield}


The sample was prepared in an acetonitrile solution with an absorption of 0.1 at $450 \mathrm{~nm}$. The sample was irradiated at $450 \mathrm{~nm}$ with a NT342B Nd-YAG pumped optical parametric oscillator (Ekspla). The emission was focused at right angle to the excitation pathway and directed to a Princeton Instruments Acton SP-2300i monochromator. The signal was detected with a XPIMax 4 CCD camera (Princeton Instruments). The luminescence quantum yields were determined by comparison with the reference $\left[\mathrm{Ru}\left(2,2^{\prime} \text {-bipyridine }\right)_{3}\right] \mathrm{Cl}_{2}$ in acetonitrile $\left(\Phi_{\mathrm{em}}=5.9 \%{ }^{55}\right)$ applying the following formula:

$$
\begin{gathered}
\Phi_{\text {em, sample }}=\Phi_{\text {em, reference }} *\left(\mathrm{~F}_{\text {reference }} / \mathrm{F}_{\text {sample }}\right) *\left(\mathrm{I}_{\text {sample }} / \mathrm{I}_{\text {reference }}\right) *\left(\mathrm{n}_{\text {sample }} / \mathrm{n}_{\text {reference }}\right)^{2} \\
\mathrm{~F}=1-10^{-\mathrm{A}} \text { (3) }
\end{gathered}
$$

$\Phi_{\mathrm{em}}=$ luminescence quantum yield, $\mathrm{F}=$ fraction of light absorbed, $\mathrm{I}=$ integrated emission intensities, $\mathrm{n}=$ refractive index, $\mathrm{A}=$ absorbance of the sample at irradiation wavelength.

\section{Lifetime}

The sample was prepared in an air saturated as well as a degassed acetonitrile solution with an absorption of 0.2 at $450 \mathrm{~nm}$. The sample was irradiated at $450 \mathrm{~nm}$ with a NT342B Nd-YAG pumped optical parametric oscillator (Ekspla). The emission was focused at right angle to the excitation pathway and directed to a Princeton Instruments Acton SP-2300i monochromator. The signal was detected with a R928 photomultiplier tube (Hamamatsu).

\section{Singlet oxygen - direct evaluation:}

The sample was prepared in an air saturated acetonitrile or $\mathrm{D}_{2} \mathrm{O}$ solution with an absorption of 0.2 at $450 \mathrm{~nm}$. The sample was irradiated at $450 \mathrm{~nm}$ with a mounted M450LP1 LED (Thorlabs) whose light was focused with aspheric condenser lenses. Using a T-Cube LED Driver (Thorlabs), the intensity of the irradiation was varied and monitored with an optical power and energy meter. The emission was focused at right angle to the excitation pathway and directed to a Princeton Instruments Acton SP-2300i monochromator. To cut off light at wavelengths shorter than $850 \mathrm{~nm}$, a longpass glass filter was placed in front of the monochromator entrance 
slit. The signal was detected with an EO-817L IR-sensitive liquid nitrogen cooled germanium diode detector (North Coast Scientific Corp.). The luminescence signal, centered at $1270 \mathrm{~nm}$, was measured from 1100 to $1400 \mathrm{~nm}$. The obtained data was analyzed upon plotting the integrated luminescence peaks against the percentage of the irradiation intensity. The slope of the linear regression was calculated and compared with the reference Rose Bengal $\left(\Phi=76 \%{ }^{74}\right)$. The absorption of the sample was corrected with an absorption correction factor. The singlet oxygen quantum yields were calculated using the following formula:

$$
\begin{gathered}
\Phi_{\text {sample }}=\Phi_{\text {reference }} *\left(\mathrm{~S}_{\text {sample }} / \mathrm{S}_{\text {reference }}\right) *\left(\mathrm{I}_{\text {reference }} / \mathrm{I}_{\text {sample }}\right) \\
\mathrm{I}=\mathrm{I}_{0} *\left(1-10^{-\mathrm{A}}\right)
\end{gathered}
$$

$\Phi=$ singlet oxygen quantum yield, $\mathrm{S}=$ slope of the linear regression of the plot of the areas of the singlet oxygen luminescence peaks against the irradiation intensity, $\mathrm{I}=$ absorption correction factor, $\mathrm{I}_{0}=$ light intensity of the irradiation source, $\mathrm{A}=$ absorption of the sample at irradiation wavelength.

\section{Singlet oxygen - indirect evaluation:}

Measurement in acetonitrile: The sample was prepared in an air-saturated acetonitrile solution with an absorption of 0.2 at the irradiation wavelength, $N, N$-dimethyl-4-nitrosoaniline aniline (RNO, $24 \mu \mathrm{M})$ and imidazole $(12 \mathrm{mM})$. Measurement in PBS buffer: The sample was prepared in an air-saturated PBS solution containing the complex with an absorption of 0.2 at the irradiation wavelength, $N, N$-dimethyl-4-nitrosoaniline aniline (RNO, $20 \mu \mathrm{M})$ and histidine (10 $\mathrm{mM}$ ). The samples were irradiated for various time points with an Atlas Photonics LUMOS BIO irradiator. The absorption of the samples was constantly monitored with a SpectraMax M2 Microplate Reader (Molecular Devices). The difference in absorption ( $\left.\mathrm{A}_{0}-\mathrm{A}\right)$ at $420 \mathrm{~nm}$ for the measurement in acetonitrile or at $440 \mathrm{~nm}$ for the measurement in PBS was determined. The difference in absorption was then plotted against the irradiation times and the slope of the linear regression calculated. The absorption of the sample was corrected with an absorption 
correction factor. The singlet oxygen quantum yields were calculated using the same formulas as used for the direct evaluation.

\section{Gel electrophoresis}

Acrylamide/bisacrylamide $(29: 1,40 \%)$ was obtained from Fisher Scientific. Visualization of PAGE gels was performed by fluorescence imaging using a Typhoon Trio phosphorimager with the ImageQuant software from GE Healthcare. Samples were loaded in blue loading dye (70\% formamide, EDTA $50 \mathrm{mM}$, 0.1\% bromophenol blue, $0.1 \%$ xylene cyanol, $\mathrm{H}_{2} \mathrm{O}$ ).

\section{CD spectroscopy}

Circular dichroism experiments were performed on a Aviv 215 spectropolarimeter at $37^{\circ} \mathrm{C}$. Concentration of AS1411 and Ru-AS1411s was kept constant (10 $\mu \mathrm{M}$ in water) and CD measured using a $1 \mathrm{~cm}$ pathlength cuvette. Stock salt solutions $(1 \mathrm{M} \mathrm{KCl}$ and $\mathrm{NaCl})$ were used. CD spectra were recorded at the Molecular Biophysics platform at Institut Pasteur.

\section{Thermal difference spectra}

TDS were performed on an Agilent Cary UV-Vis Compact Peltier machine in $60 \mu$ volume quartz cuvettes. The UV/Vis absorption spectra of concentrations of around $3 \mu \mathrm{M}$ were measured between $335 \mathrm{~nm}$ and $220 \mathrm{~nm}$ at $20^{\circ} \mathrm{C}$ and $90{ }^{\circ} \mathrm{C}$. The TDS was generated by subtracting the spectra at $20^{\circ} \mathrm{C}$ from those at $90^{\circ} \mathrm{C}$ following a previously published protocol ${ }^{64}$.

\section{Cell culture experiments}

Cells lines were treated in appropriate cell culture media of DMEM (Gibco, LifeTechnologies, USA) supplemented with $10 \%$ foetal calf serum (FCS) for the HT29 and MCF-7 cell lines (Gibco) and DMEM/F-12 (Gibco) supplemented with 10\% foetal calf serum (Gibco) for the RPE-1 cell line. All media was also supplemented with $100 \mathrm{U} / \mathrm{ml}$ penicillin-streptomycin mixture (Gibco). Cells were incubated at $37{ }^{\circ} \mathrm{C}$ in $5 \% \mathrm{CO}_{2}$. Cells were passaged when $80 \%$ confluency was reached and used within 15 passages from initial purchase. Ru-AS1411s were stored at $20 \mu \mathrm{M}$ in sterile $50 \mathrm{mM} \mathrm{KCl}$. RuN3 was stored in DMSO at $10 \mathrm{mM}$. 


\section{Cytotoxicity experiments}

96 well dishes were seeded with MCF-7 cells (6000 cells/well) or RPE-1 cells (4000 cells/well) and incubated overnight. Cell media was replaced with treatment solutions prepared to the concentrations specified and incubated for 2 or 4 hours. Concentrations of additional $\mathrm{KCl}$ (5 $\mathrm{mM})$ and DMSO $(0.01 \%)$ were kept constant across treatments. Following the incubation, wells were washed $(2 \mathrm{X}$ PBS $)$ and the media replaced $(100 \mu \mathrm{l})$ before either being treated with light $\left(\lambda_{\text {exc }}=480 \mathrm{~nm}, 3.21 \mathrm{~J} \mathrm{~cm}^{-2}, 10 \mathrm{~min}\right)$ or kept in the dark. After $48 \mathrm{hr}$ incubation the cells were treated with resazurin $\left(0.2 \mathrm{mg} \mathrm{mL}^{-1}\right.$ final concentration in appropriate media) and incubated a further $4 \mathrm{~h}$. The plates were read by fluorescence plate reader SpectraMax M5 micro plate reader $\left(\lambda_{\mathrm{ex}}, 540 \mathrm{~nm} ; \lambda_{\mathrm{em}}, 590 \mathrm{~nm}\right)$.

\section{Confocal microscopy}

Sterilized 12 mm Menzel- Gläser coverslips were added to 6 well dishes ( 3 coverslips/ well) and seeded with cells $\left(2 \times 10^{5}\right.$ cells/ well for HT-29 and MCF-7 cell lines and $1.5 \times 10^{5}$ for RPE-1) and incubated overnight. For Ru-AS1411s imaging, coverslips were transferred to separate wells in a 12-well dish and treatment solutions added. Following a 2 hour time point the wells were washed ( $3 \mathrm{X} \mathrm{PBS})$ and treated with paraformaldehyde (4\% in PBS, 15 mins) before being washed (3 X PBS) and mounted to microscope slides (Prolong Glass Antifade Mountant). For anti-nucleolin staining coverslips were transferred to separate wells in a 12well dish and incubated with Nucblue ( 2 drops/ml in media, 20 mins) before being washed (3 $\mathrm{X}$ PBS) and treated with paraformaldehyde (4\% in PBS, 15 mins) before being washed again (3 X PBS). Blocking solution was added (0.2\% BSA, 0,05\% Saponin in PBS) for $15 \mathrm{~min}$ at RT. The primary antibody anti-nucleolin (ZN004, Thermofisher) was added (5 $\mu \mathrm{g} / \mathrm{ml}, 1 \mathrm{hr}$ ) before the cover slips were washed ( 3 X 0.2\% BSA, 0,05\% Saponin in PBS) and the secondary antibody added Alexa 488 conjugated secondary antibodies (Jackson ImmunoResearch Laboratory, 1:400 dilution, $30 \mathrm{~min}$ ). The coverslips were then mounted to microscope slides 
(Prolong Glass Antifade Mountant). The slides were then imaged. For the Ru-AS1411s $\lambda_{\text {exc }}=$ $405 \mathrm{~nm}$ and $\lambda_{\mathrm{em}}=600-750 \mathrm{~nm}$. The microscope DAPI imaging settings were used for Nucblue and $\lambda_{\mathrm{exc}}=488 \mathrm{~nm}, \lambda_{\mathrm{em}}=510-540 \mathrm{~nm}$ used to image the secondary antibody. Images were recorded at the Cellular and Molecular Imaging Technical Platform, INSERMUMS025CNRSUMS3612, Faculty of Pharmacy of Paris, Paris Descartes University, Paris, France.

\section{$T_{\mathrm{m}}$ measurements}

The melting experiments were performed on an Agilent Cary UV-Vis Compact 3500 Peltier machine in $60 \mu \mathrm{l}$ volume quartz cuvettes. AS1411 samples were prepared in $0.1 \mathrm{M} \mathrm{KCl}$ to yield a solution with $\mathrm{OD}_{295}$ between 0.3 and 0.6 . Paraffin oil $(100 \mu \mathrm{l})$ was added. A control cell $(0.1$ $\mathrm{M} \mathrm{KCl}$ ) was prepared into which the temperature probe was placed. The Tm values were measured with a total of three heating and cooling ramps each $\left(1{ }^{\circ} \mathrm{C} /\right.$ minute $)$ with data processed from the heating ramps.

\section{Media stability tests}

Samples of all three Ru-AS1411s (20 pmol each, $1 \mu \mathrm{L}$ from $20 \mu \mathrm{M}$ sample in $50 \mathrm{mM} \mathrm{KCl}$ ) were incubated in cell culture medium (DMEM with 10\% FCS, $10 \mu 1$ each) and incubated for the stated time at $37^{\circ} \mathrm{C}$. Blue loading dye was added $(10 \mu \mathrm{l})$ and sampled heated $\left(95^{\circ} \mathrm{C}, 5 \mathrm{~min}\right)$ before being loaded on PAGE gel. 


\section{Acknowledgements}

We thank Dr. Philippe Goldner for access to state-of-the-art laser apparatus. We thank financial support from the Technology Transfer and Industrial Partnership Department (DARRI) of Institut Pasteur (grant INNOV 17-19) and the Joe W. and Dorothy Doresett Brown Foundation (exploratory and advanced grants). This work was financially supported by an ERC Consolidator Grant PhotoMedMet to G.G. (GA 681679), has received support under the program "Investissements d' Avenir" launched by the French Government and implemented by the ANR with the reference ANR-10-IDEX-0001-02 PSL (G.G.). L. K. M. thanks the ARC Foundation for cancer research for a postdoctoral Research Fellowship (grant number: SFB18006). A.G also thanks the ARC Foundation for cancer research for a postdoctoral Research Fellowship. The authors acknowledge a DIM1Health 2019 grant from the Région Ile de France to the project EpiK (coordinated by P.B. Arimondo) for the LCMS equipment.

\section{Competing interests}

The authors declare no competing financial interests.

\section{References}

1. J. Karges, F. Heinemann, M. Jakubaszek, F. Maschietto, C. Subecz, M. Dotou, R. Vinck, O. Blacque, M. Tharaud, B. Goud, E. Viñuelas-Zahinos, B. Spingler, I. Ciofini and G. Gasser, Journal of the American Chemical Society, 2020, 142, 6578-6587.

2. S. Monro, K. L. Colón, H. Yin, J. Roque III, P. Konda, S. Gujar, R. P. Thummel, L. Lilge, C. G. Cameron and S. A. McFarland, Chemical Reviews, 2018, 119, 797-828.

3. L. K. McKenzie, H. E. Bryant and J. A. Weinstein, Coordination Chemistry Reviews, 2019, 379, 2-29.

4. F. Heinemann, J. Karges and G. Gasser, Accounts of Chemical Research, 2017, 50, 2727-2736.

5. J. D. Knoll and C. Turro, Coordination Chemistry Reviews, 2015, 282, 110-126.

6. C. Mari, V. Pierroz, S. Ferrari and G. Gasser, Chemical Science, 2015, 6, 2660-2686.

7. S. A. McFarland, A. Mandel, R. Dumoulin-White and G. Gasser, Current Opinion in Chemical Biology, 2020, 56, 23-27.

8. M. G. Walker, P. J. Jarman, M. R. Gill, X. Tian, H. Ahmad, P. A. Reddy, L. McKenzie, J. A. Weinstein, A. J. Meijer and G. Battaglia, Chemistry-A European Journal, 2016, 22, 5996-6000. 
9. F. E. Poynton, S. A. Bright, S. Blasco, D. C. Williams, J. M. Kelly and T. Gunnlaugsson, Chemical Society Reviews, 2017, 46, 7706-7756.

10. L. Zeng, P. Gupta, Y. Chen, E. Wang, L. Ji, H. Chao and Z.-S. Chen, Chemical Society Reviews, 2017, 46, 5771-5804.

11. C. S. Burke, A. Byrne and T. E. Keyes, Journal of the American Chemical Society, 2018, 140, 6945-6955.

12. P. S. Felder, S. Keller and G. Gasser, Advanced Therapeutics, 2020, 3, 1900139.

13. M. Jakubaszek, B. Goud, S. Ferrari and G. Gasser, Chemical Communications, 2018, 54, 13040-13059.

14. S. Chakrabortty, B. K. Agrawalla, A. Stumper, N. M. Vegi, S. Fischer, C. Reichardt, M. Kögler, B. Dietzek, M. Feuring-Buske and C. Buske, Journal of the American Chemical Society, 2017, 139, 2512-2519.

15. D. Cullinane, K. S. Gkika, A. Byrne and T. E. Keyes, Journal of Inorganic Biochemistry, 2020, 207, 111032.

16. A. Martin, A. Byrne, C. S. Burke, R. J. Forster and T. E. Keyes, Journal of the American Chemical Society, 2014, 136, 15300-15309.

17. J. Karges, M. Jakubaszek, C. Mari, K. Zarschler, B. Goud, H. Stephan and G. Gasser, ChemBioChem, 2020, 21, 531-542.

18. W. Sun, S. Li, B. Häupler, J. Liu, S. Jin, W. Steffen, U. S. Schubert, H. J. Butt, X. J. Liang and S. Wu, Advanced Materials, 2017, 29, 1603702.

19. N. Soliman, L. K. McKenzie, J. Karges, E. Bertrand, M. Tharaud, M. Jakubaszek, V. Guérineau, B. Goud, M. Hollenstein and G. Gasser, Chemical Science, 2020, 11, 2657 2663.

20. E. Villemin, Y. C. Ong, C. M. Thomas and G. Gasser, Nature Reviews Chemistry, 2019, 3, 261-282.

21. Y. Ellahioui, M. Patra, C. Mari, R. Kaabi, J. Karges, G. Gasser and S. Gómez-Ruiz, Dalton Transactions, 2019, 48, 5940-5951.

22. J. Karges, J. Li, L. Zeng, H. Chao and G. Gasser, ACS Applied Materials \& Interfaces, 2020, 12, 54433-54444.

23. J. Yan, T. Gao, Z. Lu, J. Yin, Y. Zhang and R. Pei, ACS Applied Materials \& Interfaces, 2021, 13, 27749-27773.

24. P. Röthlisberger and M. Hollenstein, Advanced Drug Delivery Reviews, 2018, 134, 321.

25. L. K. McKenzie, R. El-Khoury, J. D. Thorpe, M. J. Damha and M. Hollenstein, Chemical Society Reviews, 2021.

26. L. Li, S. Xu, H. Yan, X. Li, H. S. Yazd, X. Li, T. Huang, C. Cui, J. Jiang and W. Tan, Angewandte Chemie International Edition, 2021, 60, 2221-2231.

27. P. J. Bates, D. A. Laber, D. M. Miller, S. D. Thomas and J. O. Trent, Experimental and Molecular Pathology, 2009, 86, 151-164.

28. C. M. Berger, X. Gaume and P. Bouvet, Biochimie, 2015, 113, 78-85.

29. C. R. Ireson and L. R. Kelland, Molecular Cancer Therapeutics, 2006, 5, 2957-2962.

30. Y.-A. Shieh, S.-J. Yang, M.-F. Wei and M.-J. Shieh, ACS Nano, 2010, 4, 1433-1442.

31. Q. Liu, L. Xu, X. Zhang, N. Li, J. Zheng, M. Guan, X. Fang, C. Wang and C. Shu, Chemistry-An Asian Journal, 2013, 8, 2370-2376.

32. J. Ai, Y. Xu, B. Lou, D. Li and E. Wang, Talanta, 2014, 118, 54-60.

33. J. Kim, W. Park, D. Kim, E. S. Lee, D. H. Lee, S. Jeong, J. M. Park and K. Na, Advanced Functional Materials, 2019, 29, 1900084.

34. Y. Yang, J. He, W. Zhu, X. Pan, H. S. Yazd, C. Cui, L. Yang, X. Li, L. Li and L. Cheng, Theranostics, 2020, 10, 4030. 
35. X. Zhu, H. Zhou, Y. Liu, Y. Wen, C. Wei, Q. Yu and J. Liu, Acta Biomaterialia, 2018, 82, 143-157.

36. L. Xu, X. Chen, J. Wu, J. Wang, L. Ji and H. Chao, Chemistry-A European Journal, 2015, 21, 4008-4020.

37. D. Sun, Y. Liu, D. Liu, R. Zhang, X. Yang and J. Liu, Chemistry-A European Journal, 2012, 18, 4285-4295.

38. G.-L. Liao, X. Chen, L.-N. Ji and H. Chao, Chemical Communications, 2012, 48, 10781-10783.

39. E. Wachter, D. Moyá, S. Parkin and E. C. Glazer, Chemistry-A European Journal, 2016, 22, 550-559.

40. G. Piraux, L. Bar, M. Abraham, T. Lavergne, H. Jamet, J. Dejeu, L. Marcélis, E. Defrancq and B. Elias, Chemistry-A European Journal, 2017, 23, 11872-11880.

41. L. Xu, D. Zhang, J. Huang, M. Deng, M. Zhang and X. Zhou, Chemical Communications, 2010, 46, 743-745.

42. K. McQuaid, H. Abell, S. P. Gurung, D. R. Allan, G. Winter, T. Sorensen, D. J. Cardin, J. A. Brazier, C. J. Cardin and J. P. Hall, Angewandte Chemie International Edition, 2019, 58, 9881-9885.

43. Q. Yu, Y. Liu, C. Wang, D. Sun, X. Yang, Y. Liu and J. Liu, PloS one, 2012, 7, e50902.

44. J. Weynand, A. Diman, M. Abraham, L. Marcélis, H. Jamet, A. Decottignies, J. Dejeu, E. Defrancq and B. Elias, Chemistry-A European Journal, 2018.

45. I. Brastos, E. Alessio, M. E. Ringenberg and T. B. Rauchfuss, Inorganic Syntheses, 2010, 35, 148-163.

46. R. Caspar, C. Cordier, J. B. Waern, C. Guyard-Duhayon, M. Gruselle, P. Le Floch and H. Amouri, Inorg Chem, 2006, 45, 4071-4078.

47. C. A. Panetta, H. J. Kumpaty, N. E. Heimer, M. C. Leavy and C. L. Hussey, J Org Chem, 1999, 64, 1015-1021.

48. J. Karges, F. Heinemann, F. Maschietto, M. Patra, O. Blacque, I. Ciofini, B. Spingler and G. Gasser, Bioorg Med Chem, 2019, 27, 2666-2675.

49. J. Iley and R. Tolando, Journal of the Chemical Society, Perkin Transactions 2, 2000, 2328-2336.

50. V. G. Correia, J. C. Abreu, C. A. Barata and L. H. Andrade, Org Lett, 2017, 19, 10601063.

51. Q. Sun, Z. Kang, L. Xue, Y. Shang, Z. Su, H. Sun, Q. Ping, R. Mo and C. Zhang, Journal of the American Chemical Society, 2015, 137, 6000-6010.

52. G. Lemercier, M. Four and S. Chevreux, Coordination Chemistry Reviews, 2018, 368, $1-12$.

53. J. Karges, O. Blacque, P. Goldner, H. Chao and G. Gasser, European Journal of Inorganic Chemistry, 2019, 2019, 3704-3712.

54. J. Karges, D. Díaz-García, S. Prashar, S. Gómez-Ruiz and G. Gasser, ACS Applied Bio Materials, 2021, 4, 4394-4405.

55. K. Nakamaru, Bulletin of the Chemical Society of Japan, 1982, 55, 1639-1640.

56. J. Karges, S. Kuang, F. Maschietto, O. Blacque, I. Ciofini, H. Chao and G. Gasser, Nature Communications, 2020, 11, 1-13.

57. Y. W. Cheung, P. Röthlisberger, A. E. Mechaly, P. Weber, F. Levi-Acobas, Y. Lo, A. W. C. Wong, A. B. Kinghorn, A. Haouz, G. P. Savage, M. Hollenstein and J. A. Tanner, Proc. Natl. Acad. Sci. U.S.A., 2020, 117, 16790-16798.

58. N. Z. Fantoni, A. H. El-Sagheer and T. Brown, Chemical Reviews 2021, 121, 7122 7154.

59. D. Ganz, D. Harijan and H.-A. Wagenknecht, RSC Chem. Biol., 2020, 1, 86-97. 
60. S. Mack, M. F. Fouz, S. K. Dey and S. R. Das, Current Protocols in Chemical Biology, 2016, 8, 83-95.

61. I. Kejnovska, D. Renciuk, J. Palacky and M. Vorlickova, Methods Mol Biol, 2019, 2035, 25-44.

62. M. M. Dailey, M. C. Miller, P. J. Bates, A. N. Lane and J. O. Trent, Nucleic Acids Research, 2010, 38, 4877-4888.

63. Z. Bagheri, B. Ranjbar, H. Latifi, M. I. Zibaii, T. T. Moghadam and A. Azizi, International Journal of Biological Macromolecules, 2015, 72, 806-811.

64. J. Carvalho, A. Paiva, M. P. C. Campello, A. Paulo, J.-L. Mergny, G. F. Salgado, J. A. Queiroz and C. Cruz, Scientific Reports, 2019, 9, 1-12.

65. G. R. Abel Jr, Z. A. Calabrese, J. Ayco, J. E. Hein and T. Ye, Bioconjugate Chemistry, 2016, 27, 698-704.

66. K. Liu, P. K. Lat, H.-Z. Yu and D. Sen, Nucleic Acids Research, 2020, 48, 7356-7370.

67. Y. Jing, M. Cai, L. Zhou, J. Jiang, J. Gao and H. Wang, Talanta, 2020, 217, 121037.

68. M. R. Dunn, C. M. McCloskey, P. Buckley, K. Rhea and J. C. Chaput, J. Am. Chem. Soc., 2020, 142, 7721-7724.

69. E. Eremeeva, A. Fikatas, L. Margamuljana, M. Abramov, D. Schols, E. Groaz and P. Herdewijn, Nucleic Acids Res., 2019, 47, 4927-4939.

70. K. M. Rose, I. A. Ferreira-Bravo, M. Li, R. Craigie, M. A. Ditzler, P. Holliger and J. J. DeStefano, ACS Chem. Biol., 2019, 14, 2166-2175.

71. A. E. Rangel, Z. Chen, T. M. Ayele and J. M. Heemstra, Nucleic Acids Res., 2018, 46, 8057-8068.

72. A. Notaro, M. Jakubaszek, N. Rotthowe, F. Maschietto, R. Vinck, P. S. Felder, B. Goud, M. Tharaud, I. Ciofini, F. Bedioui, R. F. Winter and G. Gasser, J Am Chem Soc, 2020, 142, 6066-6084.

73. J. Dash, Z. A. Waller, G. D. Pantoş and S. Balasubramanian, Chemistry-A European Journal, 2011, 17, 4571-4581.

74. I. E. Kochevar and R. W. Redmond, Methods in enzymology, 2000, 319, 20-28. 